\title{
A Study on the Process of Studentification: A Case Study of Katubedda Neighbourhood
}

\author{
D. Sanmugarajah ${ }^{* 1}$, N. Kankanamge ${ }^{1}$, R. Ratnayake ${ }^{1}$ and S. Kariyawasam ${ }^{1}$ \\ ${ }^{1}$ Department of Town \& Country Planning, University of Moratuwa, 10400, Sri Lanka
}

\begin{abstract}
Studentification has been identified as a form of gentrification by many scholars. Spatial and socio-economic forces in an urban fabric, which are close to academic intuitions, lead to studentification. This form of gentrification is popular in many countries such as the United Kingdom and the United States of America where universities create towns and cities. Such studentification characteristics also could be identified around some of the leading universities in Sri Lanka. The University of Moratuwa is one such university in Sri Lanka where students from all over the country come for their higher education. Clearly, the impacts of university students could be observed in the immediate vicinity. Thus, this research incorporates both qualitative and quantitative tools to provide a comprehensive explanation for neighbourhood change and investigate the studentification process took place around the Moratuwa University. The process of studentification is examined through the lenses of economic, spatial and cultural changes that have occurred in the area. More than 200 occupants of residential, commercial and mixed-use establishments within a 500m walking distance from the university were interviewed to achieve the research objective. The study results show that the university has a great impact on changing the community in various dimensions such as standards of living and quality of life. The increasing demand for student accommodation has changed the entire socio-economic structure of the community living around the university. New investors have started to invest in this area targeting the students as their main consumer base. This study provides economic, social, cultural and physical evidences and the assessment can advance the understanding about the process of studentification happening in the Moratuwa university neighborhood. At the same time, negative impacts identified such as substandard buildings, rent capturing, and violation of building and land use regulations alarms the need for special regulations and strict enforcement in such neighbourhoods.
\end{abstract}

Keywords: Gentrification, Studentification, Investors, Displacement, Reinvestment, University Neighborhood

\section{Introduction}

The concept of "Neighborhoods has been evolving since the beginning of time; People move in and out, buildings are built and destroyed, infrastructure and amenities are added and removed. The neighborhood has come to be understood as the physical building block of the city for both social and political organization" (Sampson, et al., 2012). Generally, three dynamic processes can be identified as important determinants of neighborhood change: movement of people; public policies and investments; and flows of private capital (Zuk, Bierbaum, Chapple, Gorska, \& Loukaitou-Sideris, 2015).
Neighborhood change occurs through physical elements like size and density, as well as their heterogeneous demographics. Also, neighborhood change followed a natural tendency towards social equilibrium (Park, Burgess, McKenzie, \& Janowitz, 1925). Mostly, competition for neighborhood space follows, and neighborhood succession occurs when less dominant populations were forced to relocate. The dominant groups that stay establish a new equilibrium (Zuk, et al., 2015). In these conceptualizations of neighborhood change, competition for space drives locational decisions of different groups in a natural and inevitable way. Among them, one category of neighborhood change is gentrification. 
The gentrification process is common in both developing and developed countries. Among many definitions, Keating (2003) defines, gentrification as the upward change in land use to middle and upper-income residential (Keating as cited in Ebenezer Aka, 2010). In general, gentrification means the process in which wealthier people come in, renovate, and restore housing and they do other business in cities or in the places where poor people were living (Liu, 2016). Some of the other scholars state that gentrification is the cure for all the inner-city illnesses (Lees, 2000). At the same time few scholars say, it is a common issue in urbanization where people who are affected by gentrification lose their liveliness, livelihoods, and become marginalized groups all over the world (Ebenezer, 2010).

The concept of gentrification which was introduced in the early $60 \mathrm{~s}$ is being analyzed and developed over time. More new factors are being incorporated with the central theme of gentrification. Scholars have pointed that the changes in the urban environment shares some features of the gentrification and new forms of gentrification are emerging (Lees, 2000) (Holm, 2010) such as super gentrification, studentification and touristification.

Studentification has become a leading-edge process of contemporary urban changes (Kinton, 2013). When the surrounding of a higher education institute is dominated by the students and the change in socio-economic, physical, and cultural aspects is called studentification (Davison, 2009).

Ordor and others (2010) investigated the effects of studentification on the residential neighbourhoods and businesses of a university of Cape Town (UCT) suburbs (Rondebosch, Rosebank and Mowbray) and how the studentification affects the social, cultural, economic and environmental condition in the residential neighbourhood and businesses. The research revealed the existence of a unique student housing market and opens new areas of research into the patterns, distribution and implications for the formation of students' areas. Moreover, it raises the issue of the tradeoff between the apparent profitability of the student market and the implications for urban facilities management and the demographic balance in these areas.

Studentification changes an area physically, socially, economically and culturally. There are many researches have been conducted about the studentification in other countries around the university areas. Though the gentrification due to students could be observed in some Sri Lankan university neighbourhoods, yet no studies been carried to explore the process or impacts of studentification in the local context.

\subsection{Research Problem}

In Moratuwa University, the hostel facilities are limited only to the first year and the final year students (University of Moratuwa, 2017). All other students accompany themselves in private rental houses and rooms. As a result, the neighborhood started to adapt to fulfill the needs of the students. The above-mentioned factors are being observed and identified only. They have not been studied and analyzed so far. Therefore, there is a need to study the process and find out the dominating factor and its consequences.

Several neighborhood changes can be observed in the vicinity of the university such dominance of university students and their activities, conversion of houses into boarding places, commercial or mixed-used establishments, expansion of seasonal occupations targeting student population, and displacement of original residents. However there is a need for research to conceptualize this neighborhood change within the principles of gentrification, which is the aim of this particular research study.

\section{Literature review}

\subsection{Studentification as a form of Gentrification}

The term gentrification and studentification are always confusing, both are coined with each other. Recent research gives an important focus on studentification and argues that studentification fits within the large concept of gentrification (Kinton, 2013). Therefore, the studies on studentification follow the same principles of gentrification as stipulated in the rent gap theory (Smith, 1987), filtering theory (Arnott, Davidson, and Pines, 1983), and household lifecycle theory (Gober, 1992; Liu and O'Sullivan, 2016).

The gentrification term was introduced by Ruth Glass who was an urban geographer. She first introduced the word gentrification to describe the process of socio-spatial change where the rehabilitation of residential property 
in a working-class by relatively wealthy incomers makes the former residents unable to bare the increased costs of housing that accompany regeneration happened in London neighborhoods in the 1960s (Glass as cited in Liu, 2016). London neighborhoods in the $1960 \mathrm{~s}$ and experience gentrification as a process of socio-spatial change where the rehabilitation of residential property in a working-class by relatively wealthy incomers makes the former residents unable to bare the increased costs of housing that accompany regeneration (Glass as cited in Liu, 2016) (Ebenezer Aka, 2010). Features of gentrification are reinvestment of capital, social upgrading, landscape change, displacement (Davidson and Lees, 2005). The features of the gentrification differ from one to the other. For example, some scholars research regarding the displacement factor (Zuk, et al., 2015) as the primary component whereas others discuss reinvestment as the main factor (Gotham, 2015). The gentrification directly affects the real estate market, which increases the rents and mobility (Lees, 2000). Thus, gentrification plays an important role in the economic and socio-cultural structure of a society. When focusing on gentrification, there is a need to pay attention on wide a range of factors such as policy, culture, society and economy in the changing metropolitan environment. In a contemporary situation, there are many developments takes all over the world and the reasons for the development are different from one and another. For example, the developmental process will not be the same for a university and a tourist location (Sage, 2010). Therefore, there is a need to redefine the term gentrification to the contemporary changes in its process. The new factor for the urban change, which will be central to the argument over the conceptualization of gentrification will be the forms of gentrification. When students are the dominant factor of an urban change, it will be identified as studentification (Lees, 2000). By the above explanation, it can be easily understood that the recent form of changes in the rural and urban environment such as tourism and super gentrification (Butler and Lees, 2006). Studentification does not totally fit with the parameters introduced by Ruth Glass, but they share some basic characters of gentrification.

\subsection{Forms of Neighbourhood Change with Studentification}

The studentification term was introduced by Dr. Darren Smith of the School of Environment at the University of Brighton. He has analyzed the groups created in British college towns by young students. He strongly says studentification is often the incubator for gentrification (Davison, 2009). Accordingly, the processes of studentification imply urban changes which are tied with the commodification of 'single-family' or the repackaging of existing private rented housing, by small scale institutional actors such as property owners, investors and developers to produce and supply houses in multiple occupations for higher education students (Smith, 2002). The word studentification is engaged with the seasonal migration of higher education students and clarifies the development of high concentration of such kind of students among the neighborhood of the universities. Studentification indicates the urban changes which bring about unique social, cultural, economic and physical changes within the university neighborhood (Smith, 2002). Further, Smith explained that the process of studentification in the same vein of gentrification. The development of the high education institutes by the government without the facilities to deal with the effects on student accommodation is one of the reasons of studentification (Sage, 2010).

Briefly, studentification elaborates that large numbers of students invading in particular areas of the cities and towns in which popular universities are located. When students occupy the area, they cause for the changes in the social, cultural, physical and economic structure of the area. Furthermore, it describes the concentration of high numbers of university students moving into established residential neighborhoods and the distinct social, economic, cultural, and physical effects arising from this process (Smith and Holt, 2007).

The economic changes of a neighborhood start with the abnormally increasing property values due to rising students' accommodation demand. This leads to the re-commodification of small family housing units to houses in multiple occupations for students. This modification of the housing gives a monthly income or profit for the landlord and limits the levels of owner-occupation. This restructuring of the housing stock gives rise to a tenure profile which is dominated by private rented 
and decreasing levels of owner-occupation (Kinton, 2013). The social changes come in forms of replacement or displacement of a group of former residents with a transient, involving new patterns of social concentration and segregation. For example, generally there may be young and single or middle-class social grouping. Enlisting of new social grouping, which includes students and social people regardless of income level (Hubbard, 2008).

The Cultural changes of the neighborhood are with the assembling of with a reputed mixed shared culture and lifestyle, and consumption behaviors of students' create a different type of retail and administration framework. Where diverse cultural changes and interconnection are being introduced to the social spectrum. Some say that the cultural synthesis is a process that can be identified here (Smith and Holt, 2007). Physical changes involve with upgrading of the surrounding environment as properties are converted to houses in multiple occupation. Consequently, this will lead to downgrading of the physical condition, depending on neighborhood context (Ordor, et al., 2010).
Figure 1 below conceptualize the studentification within the broader frame of gentrification using above discussed literature:

Mostly, studentification is seen as a negative consequence, as in context phrased as "student ghetto". It explains the quick transformation of consumption and residential area which suits the student demands. For example, the spread of takeaway food outlets and discounted liquor retailers, and the change of larger residential properties into houses in multiple occupancy (Smith D. P., 2006). Studentification also involves with social and financial outcomes and it is demonstrated by the decrease in school class sizes as families move out of such areas and increase the prices of houses as landowners create a property boom (Ordor, Cattell, Michell, \& Bowen, 2010).

Table 01 below further details the four (04) basic features of studentification into measurable indicators:

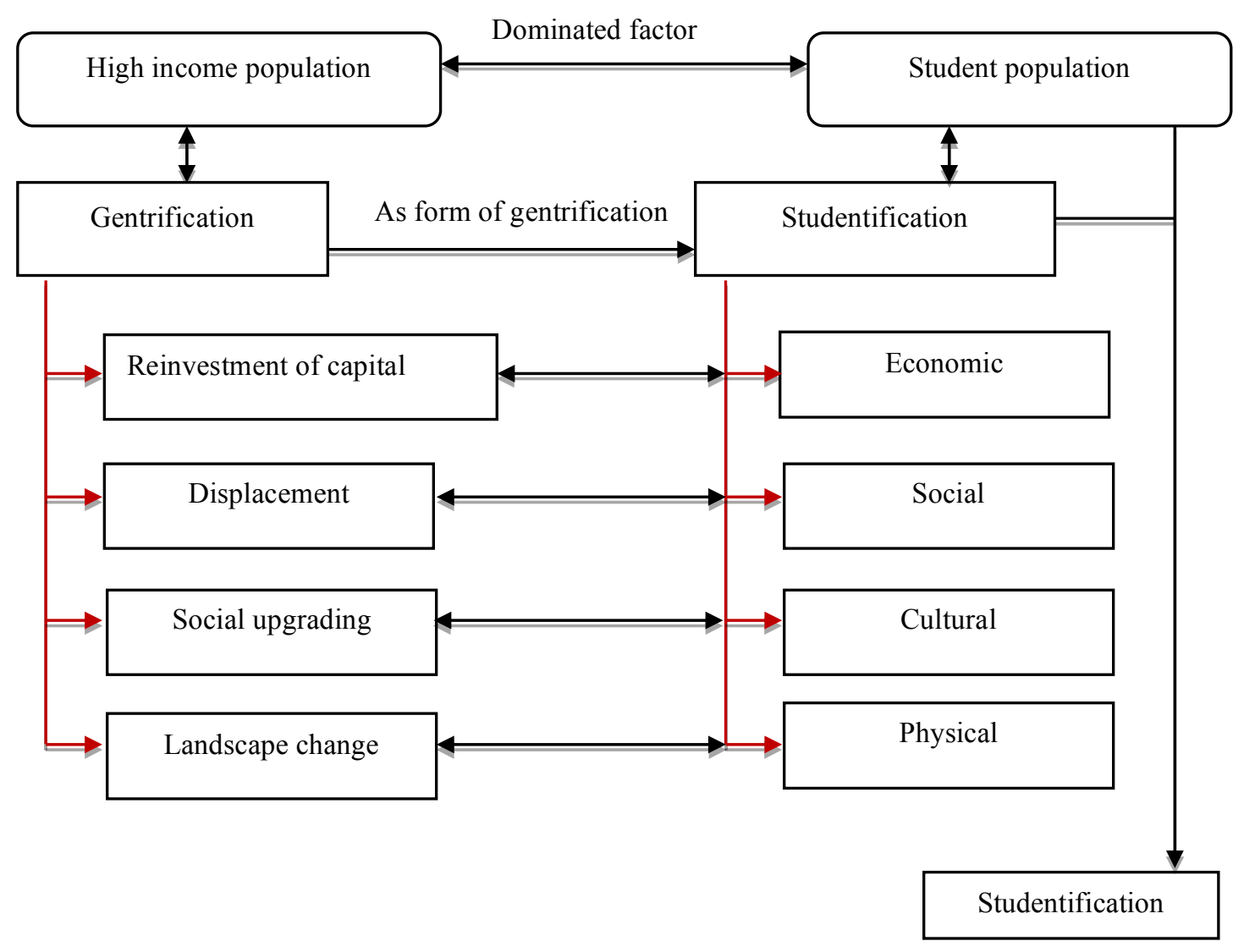

Figure 1. Conceptual diagram Source: Compiled by authors 
Table 1: Indicators of studentification

\begin{tabular}{|c|c|c|}
\hline $\begin{array}{c}\text { Features of } \\
\text { Studentification }\end{array}$ & $\begin{array}{l}\text { Indicators of } \\
\text { Studentification }\end{array}$ & Explanation \\
\hline \multirow{5}{*}{ 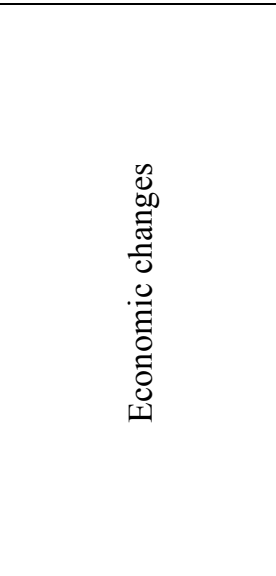 } & $\begin{array}{l}\text { Houses with multiple } \\
\text { occupation (HMO) }\end{array}$ & $\begin{array}{l}\text { Conversion of the household into student residences and } \\
\text { commercial places. }\end{array}$ \\
\hline & $\begin{array}{l}\text { Value of property / } \\
\text { land }\end{array}$ & $\begin{array}{l}\text { The pattern of changes in land/property value where it } \\
\text { started to increase the land/property demand which led } \\
\text { to increase the value. }\end{array}$ \\
\hline & Rent rate & $\begin{array}{l}\text { How rental amount change due to the high demand for } \\
\text { accommodation by students }\end{array}$ \\
\hline & Seasonal employment & $\begin{array}{l}\text { A business which is based on students. Where they } \\
\text { function during the university period. Where the locals } \\
\text { concentrate on the income-based on university students. }\end{array}$ \\
\hline & $\begin{array}{l}\text { Incensement in } \\
\text { number of retail shops }\end{array}$ & $\begin{array}{l}\text { A group of people which target the young generation } \\
\text { with same putatively shared } \\
\text { culture and lifestyle, and consumption practices linked to } \\
\text { certain types of retail }\end{array}$ \\
\hline \multirow{2}{*}{ 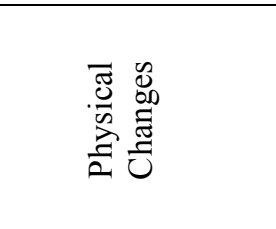 } & $\begin{array}{l}\text { Improvement in } \\
\text { Infrastructure }\end{array}$ & $\begin{array}{l}\text { Development of infrastructure facility by student society } \\
\text { in the specific area }\end{array}$ \\
\hline & $\begin{array}{l}\text { private rented } \\
\text { accommodation } \\
\text { and apartment }\end{array}$ & $\begin{array}{l}\text { Construction of new accommodation facilities which } \\
\text { provide by private sectors for students }\end{array}$ \\
\hline \multirow{2}{*}{ 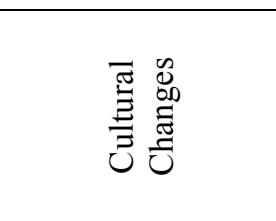 } & Cultural activities & $\begin{array}{l}\text { Culture and life style which are based on student society. } \\
\text { And synthesis of variable cultures. Plus, cultural } \\
\text { hybridization. }\end{array}$ \\
\hline & $\begin{array}{l}\text { Reduction of number } \\
\text { of crimes }\end{array}$ & $\begin{array}{l}\text { Reduction of the social crime activities in a remote area } \\
\text { where a social buffer has been created by the students. }\end{array}$ \\
\hline \multirow{3}{*}{ 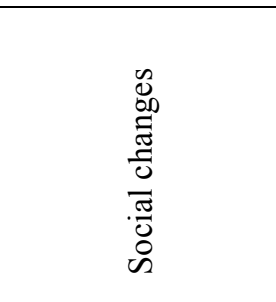 } & $\begin{array}{l}\text { Growth of student } \\
\text { numbers in local } \\
\text { context. }\end{array}$ & $\begin{array}{l}\text { Growth of student numbers in the locals and inspiring } \\
\text { the local society to educate them self. }\end{array}$ \\
\hline & Student density. & $\begin{array}{l}\text { Increment of student number in the area where they } \\
\text { started to dominate the population level. }\end{array}$ \\
\hline & $\begin{array}{l}\text { Displacement of } \\
\text { households. }\end{array}$ & $\begin{array}{l}\text { Changes in the owner occupation in the houses. Where } \\
\text { they migrate to another place. }\end{array}$ \\
\hline
\end{tabular}

Source: Compiled by authors based on (Kinton, 2013) (Smith and Holt, 2007) (Davison, 2009) (Smith, 2006) (Ordor et al., 2010) (Sabri and Ludin, 2009) (Sage, 2010)

\section{Method of investigating Studentification}

There are several reasons for the selection of Katubedda neighborhood as the case study area. Katubedda is one of the suburb (Grama Niladhari Division2) in the Moratuwa city. Katubedda plays a major role as an example of a small town where a university is located and its students are more 'apparent' than university neighborhoods in larger cities like Colombo.

The history of Moratuwa University is characterized by its rapid development: it was founded as a technical institute and then awarded university status in 1972. The Katubedda campus began with one faculty, which is faculty of Engineering and Architecture. At present there are five faculties, which are Architecture, Engineering, Information Technology, Business, and Graduate Studies. Because of the increment of education opportunities, the student population has been increased in last few decades. Since student hostel facilities are being provided only for selected candidates in first and final years of study, the demand for private boarding facilities has increased rapidly. In order to cater this demand new market is observed targeting the 
university students within the university neighborhood.

Accordingly, Katubedda neighborhood features the domination of students' occupation in the society. Based on the above observations this research selected Katubedda neighborhood as a case study to study the student gentrification process.

The boundary of the case study area is defined as properties and activities within $500 \mathrm{~m}$ standard walking distance from the center of the University. Accordingly, the sample area was selected with the judgment of $500 \mathrm{~m}$ walking distance as the core influenced area of the students. It included communities located in the surroundings of the university such as John Rodrigo Mawatha, 2nd lane, Back gate, Campus Road, Molpe road and Sri Manmenika pura.

\subsection{Data Collection Methods}

The methodology of the research followed a mixed approach with both qualitative and quantitative data. It included survey instruments of Focus Group Discussions (FGDs), Questionnaire survey, Observational survey, and a secondary data collection (Table 02).

Focus group discussions were used to collect evidences on cultural and physical changes in selected communities due to the influences of university students. The participants of the FGDs were identified during questionnaire survey and based on their experience (people aged 50 years and above) on the neighborhood and to represent different groups (three-wheel drivers, shop owners, residents, etc.) Three FGDs were conducted with 5-8 participants each.

For the purpose of the questionnaire survey, 270 properties were selected to measure the Economic and Social change because of students. The sample included all the properties (residential, commercial and mixed) except institutions within $500 \mathrm{~m}$ walking distance from the university center.

Field evidences were collected through photographs and building-use mapping techniques to analyze the spatial significance of the research problem.

Secondary data included reports and documents taken from the hostel office, student registers etc which are used to attain the research question.

\section{Results and Discussion - Studentification in Katubedda Neighbourhood}

\subsection{Economic Changes}

Katubedda area was famous for timber crafting, because of its location close to Moratuwa and Bolgoda river. According to Focus Group Discussions, there were lowincome settlements in the community before the establishment of university. In 1966 a technical institute was established in Katubedda which later transformed into the University of Moratuwa.

Table 2. Data collection methods

\begin{tabular}{|l|l|l|}
\hline \multicolumn{1}{|c|}{ Indicator } & \multicolumn{1}{|c|}{ Survey instrument } & \multicolumn{1}{c|}{ Analytical approach } \\
\hline Economic changes & $\begin{array}{l}\text { Questionnaire survey } \\
\text { Secondary data } \\
\text { Field observations }\end{array}$ & Descriptive analysis \\
\hline Social changes & Questionnaire survey & Descriptive analysis \\
\hline Cultural changes & $\begin{array}{l}\text { Focus Group Discussions } \\
\text { Field observations }\end{array}$ & Content analysis using Nvivo software \\
\hline Physical changes & $\begin{array}{l}\text { Focus Group discussions } \\
\text { Field observations }\end{array}$ & Descriptive analysis \\
\hline
\end{tabular}




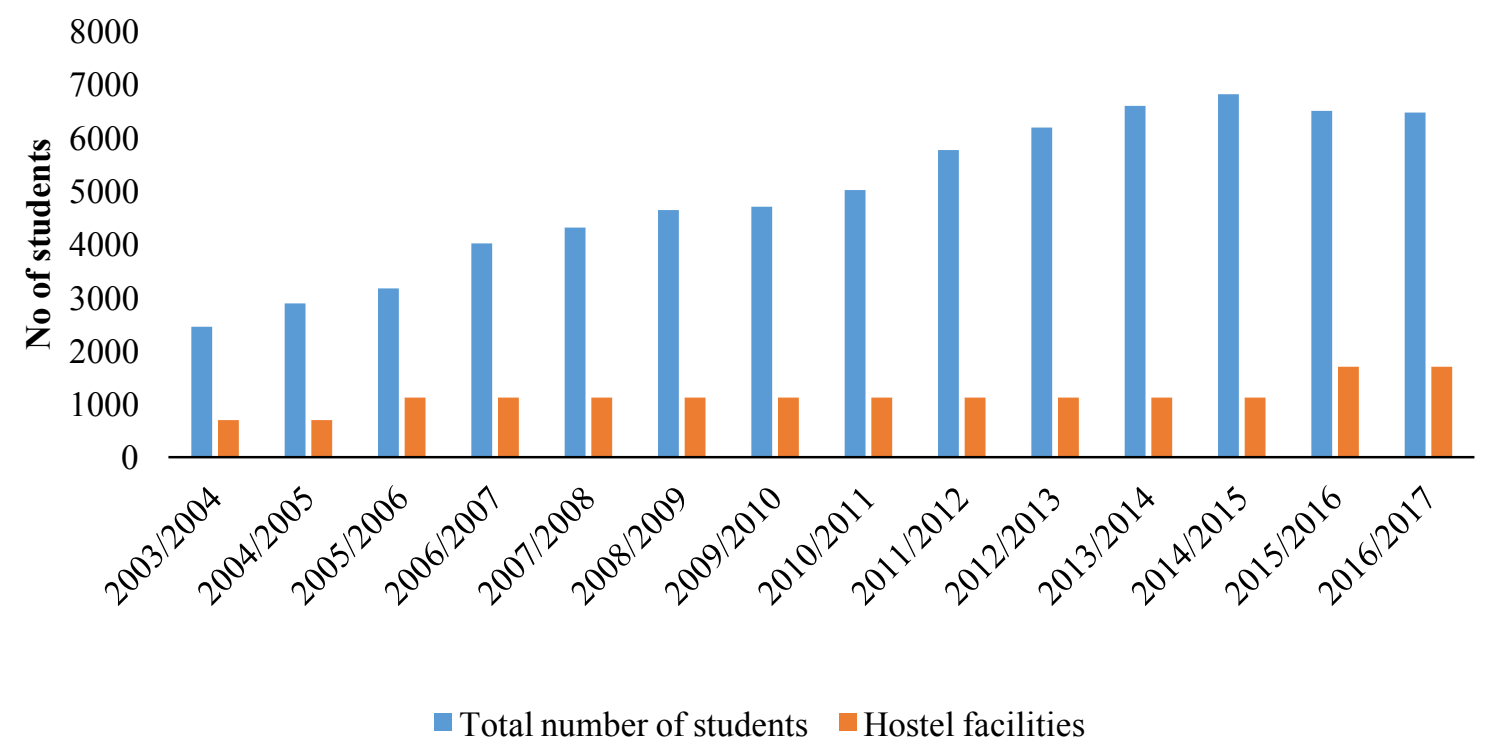

Figure 2. Number of Students vs Hostel facilities provided by the University Source: Compiled by authors

Within the time period, there was a gradual increase in student intake. In Moratuwa, there was an overall increase of 1,003 students, from 575 students in 2000/2001 to 1578 in 2016/2017. Although the university introduced new faculties and courses, the hostel facilities did not develop enough to fulfill the student's accommodation needs. As a peak, it came to a situation where only $25 \%$ of students are provided with hostel facilities (figure 2). So, they have been forced into a situation to find their own boarding places in the Katubedda neighborhood. Gradually the houses began to accommodate students for rent where this feature becomes an important factor in the economic structure of the society. Residents in the neighborhood targeted the students to gain a secondary income.

Though such converted boarding places were insignificant at the beginning (in 1999 it was $9.36 \%$ ) in the neighbourhood, it reached $41.57 \%$ of housing units by 2009 and gradually increasing there after. Now provision of student accommodation has become primary income of the inhabitants of the community. At the same time this process has resulted in various forms of student's accommodation such as boarding only, owner occupied and boarding, owner-occupied and commercial, and owner occupied, commercial and boarding (Table 03).

Table 3. Spatial Transformation of Katubedda University Neighbourhood

\begin{tabular}{|l|c|c|c|}
\hline \multicolumn{1}{|c|}{ Type of use } & $\begin{array}{c}\text { Before 1999 } \\
(\mathbf{\%})\end{array}$ & $\begin{array}{c}\mathbf{2 0 0 0} \text { to 2009 } \\
\mathbf{( \% )}\end{array}$ & $\begin{array}{c}\mathbf{2 0 1 0} \text { to 2017 } \\
\mathbf{( \% )}\end{array}$ \\
\hline Owner occupied or rented & 56.55 & 40.57 & 28.09 \\
\hline Students Boarding \& owner residence & 9.36 & 41.57 & 42.32 \\
\hline Boarding only & - & 5.99 & 15.00 \\
\hline $\begin{array}{l}\text { Owner residence, Boarding \& } \\
\text { commercial }\end{array}$ & - & - & 5.13 \\
\hline Owner residence \& commercial uses & 5.24 & 4.75 & 9.46 \\
\hline Extent of the vacant land & 28.84 & 7.12 & \\
\hline
\end{tabular}



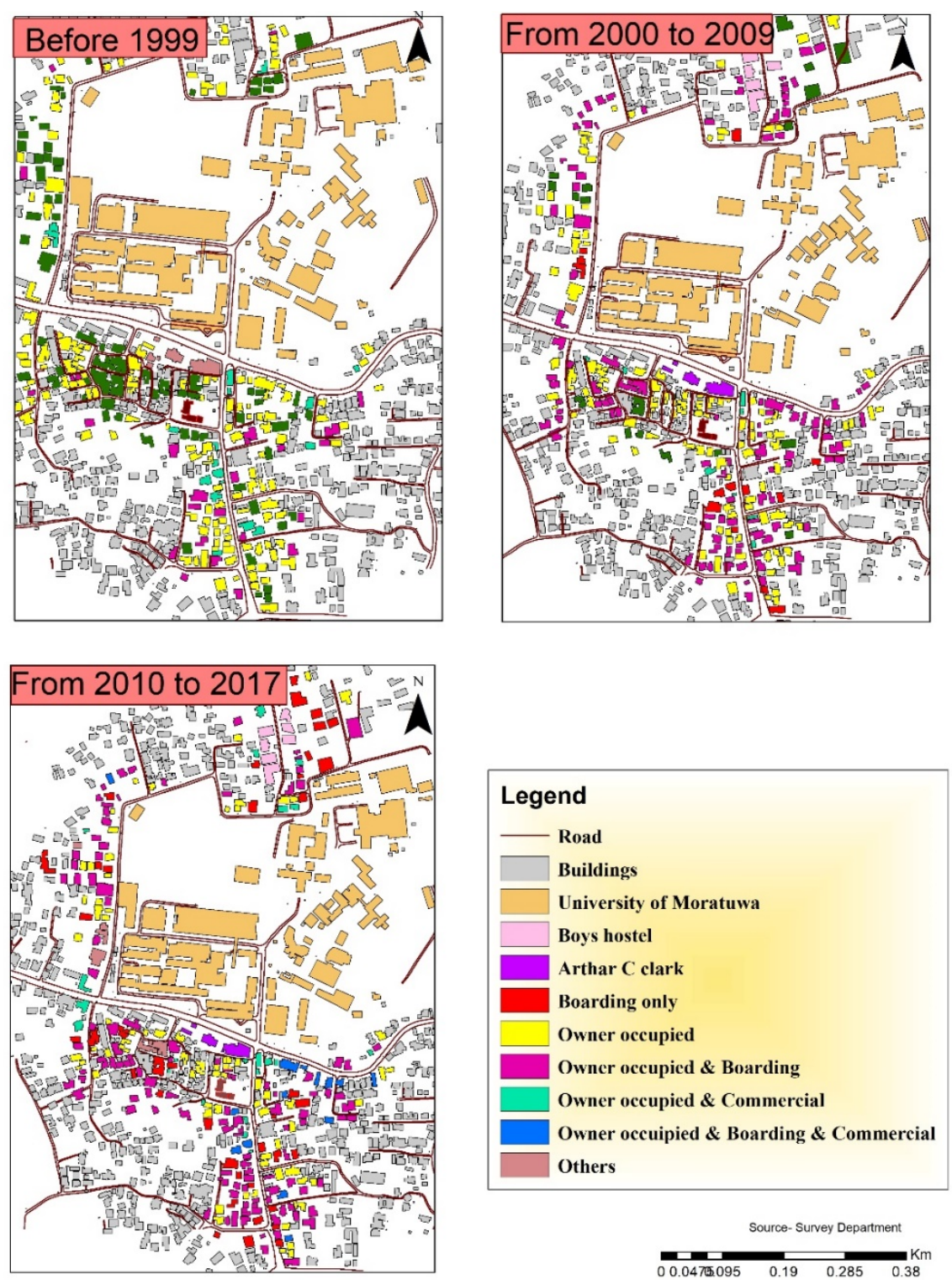

Figure 3. Spatial Transformation of Katubedda University Source: Compiled by authors

These are the new forms of student accommodation, which were introduced to address students' privacy and other needs. So, the people from the existing context used this as a good investment where they invested to upgrade or build new student accomodation and gain more income. Due to this situation, a new market uprooted for boarding places. Boarding houses near to the University, and with high level of facilities have more demand than rest. Such scenario has been discussed in rent gap theory too ( Smith N. , 1987).

\footnotetext{
${ }^{3}$ Actual rent or capitalized land rent is the rent a landlord or property owner is currently being paid for a property. Potential rent is how much a landlord or property owner could earn if they evicted current tenants and converted the property to its most
}

At the same time, students have became the reason for the increasing investments in the potential rent rate ${ }^{3}$. So, to gain the highest and best use of the land, landlords have reinvested in their land to gain more profit. Day by day third party people (private and nonresidential investors) also invested in the neighborhood to capture this potential rent.

profitable use. Student rent is the rent a landlord or property owner is currently being paid for a piece of land by the students 


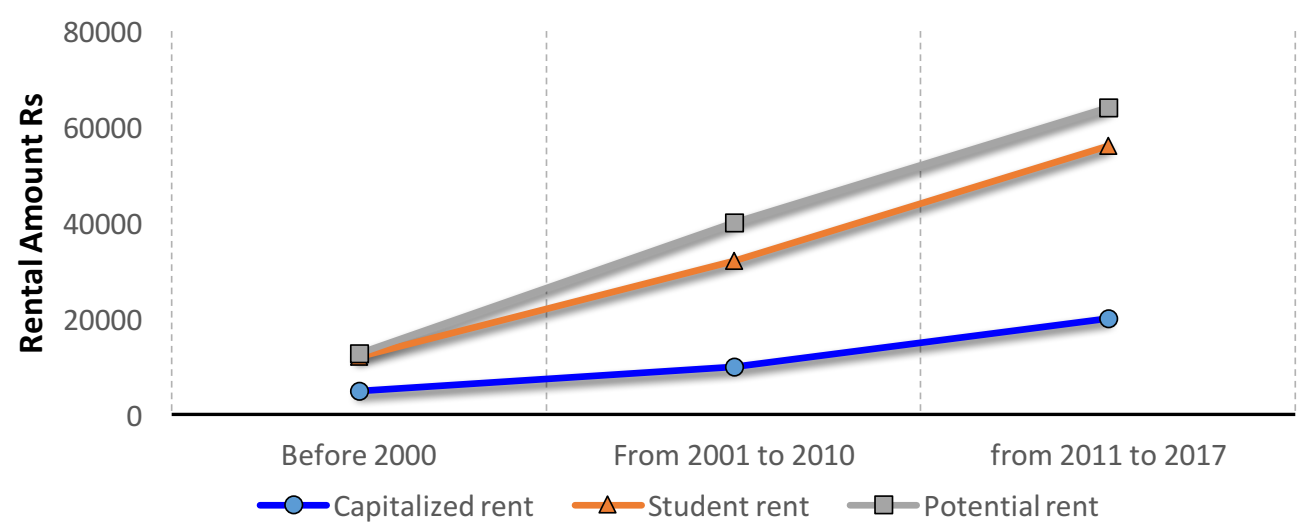

Figure 4. Rent gap

Source: Compiled by authors based on field data

The reinvestment activity within the time period of 1990 to 2007 , there was a gradual increment, but after 2008 there was a sudden pike because the number of student intake was increased. Then this change doubled in 2017 with association with the student's intake percentage where private developers invested to capture the rent gap.

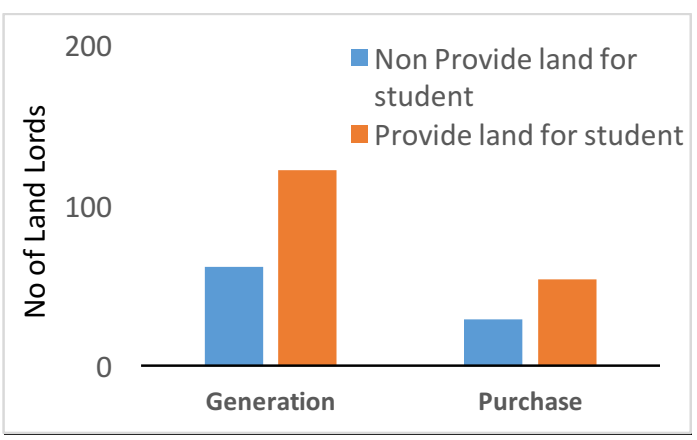

Figure 3. Land use pattern in land ownership

Source: Compiled by authors based on field data

New developers have entered into the community with the aim of generating profit and to achieve the rest of the rent gap. New developers have bought the land in the aim of gaining profit based on students. But at the same time native people purchase lands as an investment. We can clearly see a pattern where around $2 / 3$ of the purchased land (by new investors) and land from ancestors have been provided for the students' accommodation needs.

Within the collected data more than $50 \%$ of developers have purchased land targeting the students (figure 6). In other words, they try to gain profit from students by providing them accommodations and services.

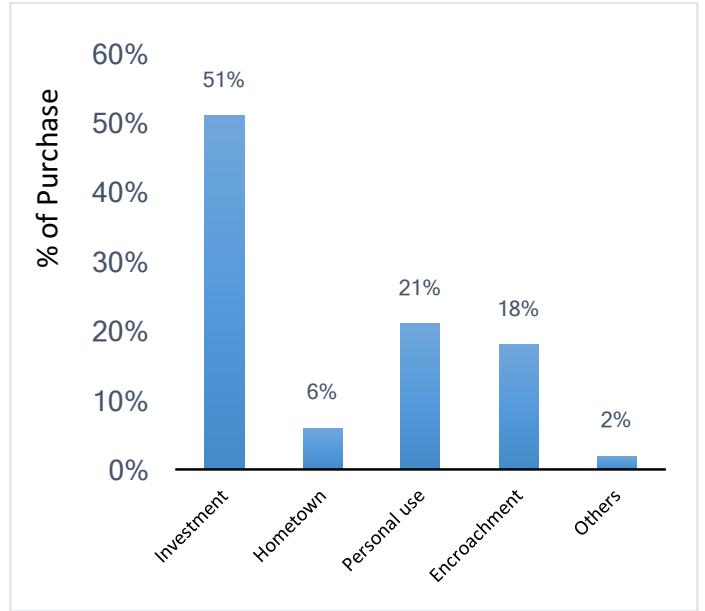

Figure 4. Reason for purchasing land area in Katubedda Campus Neighbourhood

Source: Compiled by authors based on field data

Another economic change observed in Katubedda neighborhood is Housing Multiple Occupancy (HMO) which refers to residential properties where 'common areas' exist and are shared with students (Figure 07).

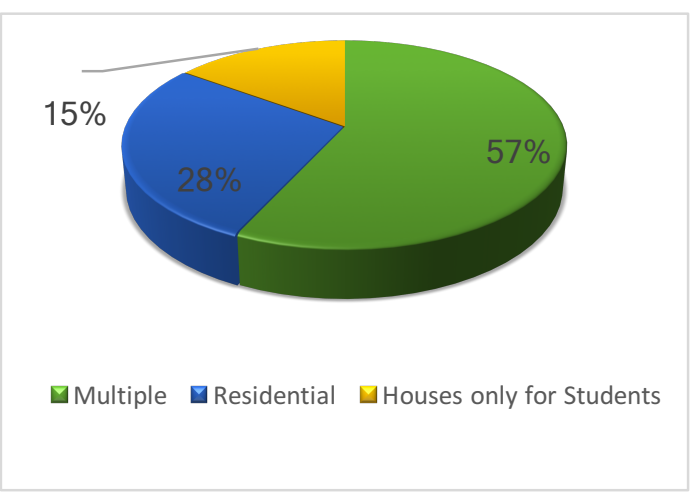

Figure 5. HMO in Katubedda university neighbourhood

Source: Compiled by authors based on field data 
By the time this research conducted it has recorded that $57 \%$ of housing units were converted to HMOs.

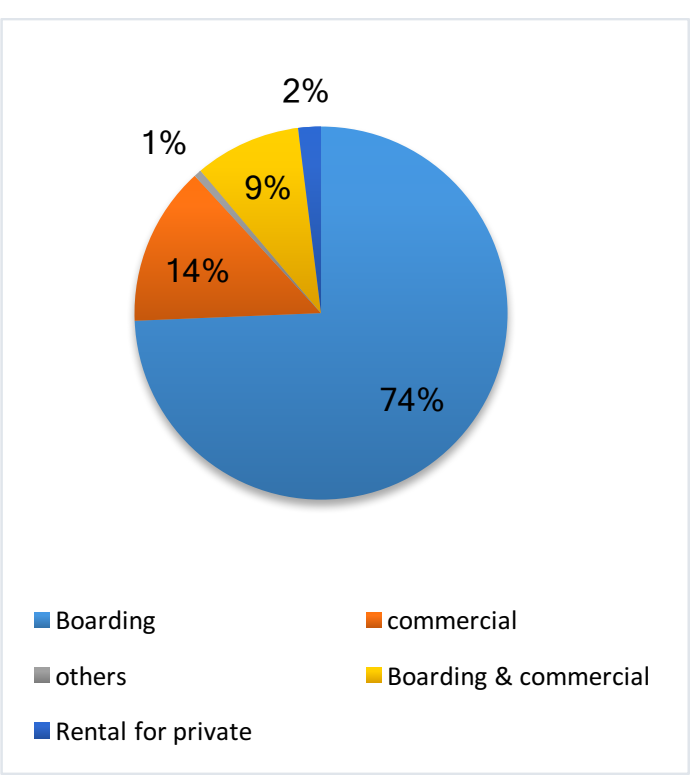

Figure 6. Various usage of HOM

Source: Compiled by authors based on field data

Further, out of $57 \%$ HMOs, around $74 \%$ of households have been allocated to the boarding, and $14 \%$ places allocated for student based commercial activity such as food outlets, printing shop, parlors, grocery shop etc. And $9 \%$ of households provided for students and commercial activity which means that places used for commercial and accommodation usage. At the same time, 3\% of the places in HMO's are not provided for the students.

In the case study area, around $70 \%$ earning activity of the society are based on the students. It consists of partial or full income to the residents thus, absence of students in the neighborhood make residents a loss of larger share of income and livelihood. During the vacation period of the university (April and December) the entire commercial community will be paused because of the absence of the student. In a nutshell, there is an enormous economic dependency on the student base.

\subsection{Social Changes}

Questionnaire survey indicates that 19\% of people has left this area (Displacement), converting their inherited house in to a boarding place and rest of the space (20\%) has been converted in to a commercial area as they leave (figure 09).

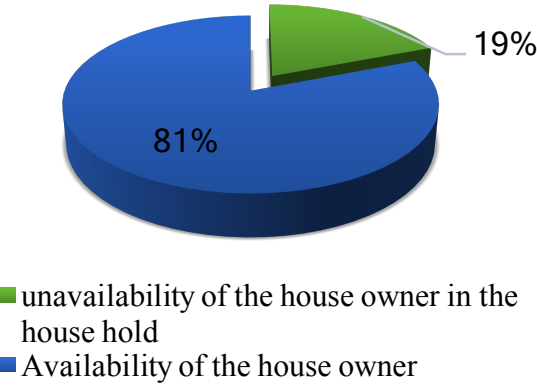

Figure 7. Land Owner Occupation Distribution

Source: Compiled by authors based on field data

The reasons for migration were mainly the potential income, educational opportunities and many other factors. They leave in a purpose to develop their lifestyle as well as to gain income. $80 \%$ of these households are being converted into boarding houses where the rest are being converted in to commercial purpose. Thus, the people who migrate from the neighborhood, use their property for a secondary income which is based on students.

In the meantime, a new feature is observed in Katubedda university neighborhood where residents provide most of their house area for the students, which reduce the owner occupancy share in a housing unit.

In present data owner occupancy rate is respectively very low. Most of the owners allocated $2 / 3$ of the area in their house for the students to board. Because they gain a good income from the students.

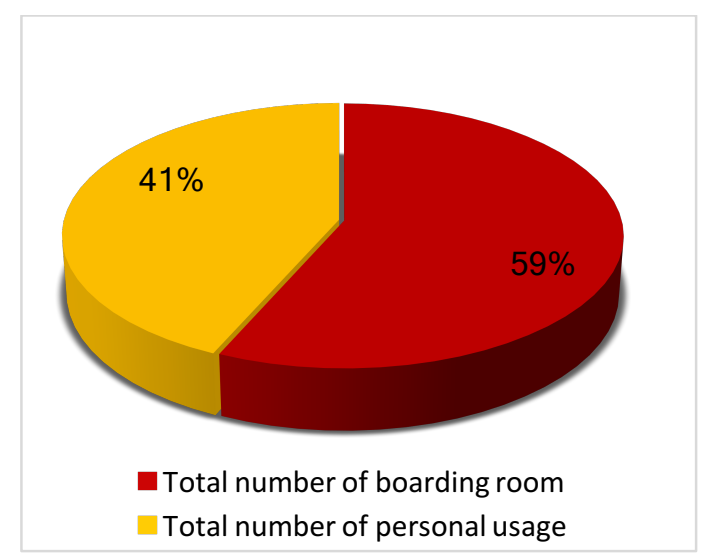

Figure 8. Share of Owner occupation in housing units

Source: Compiled by authors based on field data

Through the conversion of owner occupied area into boarding houses owner's occupation rate is reduced due to the accommodation of the students in their residents. Without considering about their own comfort, they limit their own spaces and 
provide the rest of the area to the students in order to gain more income. To our knowledge, this is unique and a new contribution to gentrification and studentification theory. In Moratuwa campus area, owners mostly occupy a part of the place and a part is given to students. In previous studies on studentification have informed us that original owners move out of the University surrounding site so that land would be developed by new investors. This fact needs to be examined further as why such trend is occurring in this locality. This may be due to the lack of very high demand for largescale private accommodation as the student numbers are relatively low compared to Metropolitan Universities such as the University of Melbourne. This is also could be due to security issues as owners think that students may damage the property. This situation may be related to local communityoriented culture that tolerates two or three families living in the same dwelling and in such living set up privacy is not the priority.

\subsection{Cultural Changes}

According to three FDGs conducted, the local residents believe that students have changed their community value and profiles towards students' culture.

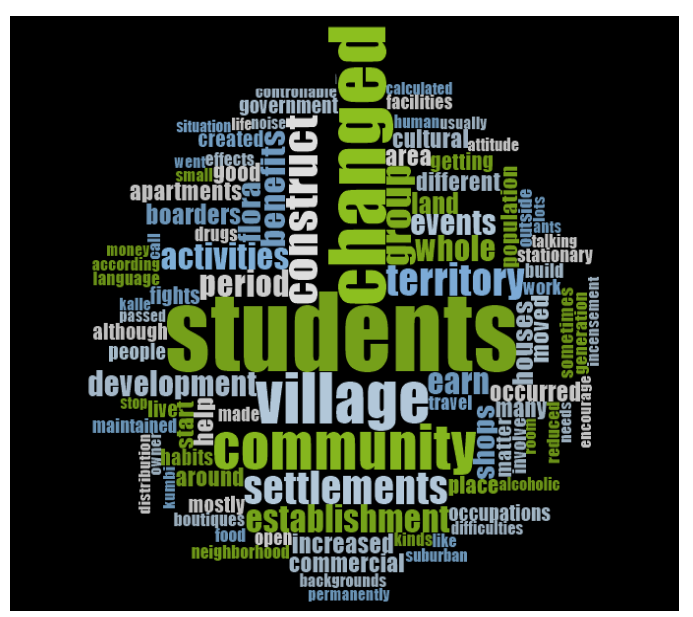

Figure 9. Cloud analysis diagram

Source - Compiled by authors

Figure 11 is the word frequency analysis results of FDG participants' comments on cultural changes due to students. Results highlights the changes such as events inspired from students, influences over language, food habits, dreams and desires, addictions and means of income.

The residences of the local community quoted below perceptions about the students in the community as follows;
1. The attitude of the local community has been changed where they started to address the positive nature of the social hybridization and cultural synthesis. Moreover, they began to adopt their lifestyle towards the emerging changes. Positive aspects are absorbed by the society in a holistic manner.

2. Because of the use of mixed language of students (Sinhala, Tamil and English), language of and accents of the local community have been evolved.

3. Students started to marry people from local community.

4. People started to educate their children and university students became an inspiration to the locals.

5. Transfer of the Institute of technology led to a big gap in society which ended up with profit maximization. It was a major impact in their income level that locals quoted.

6. Retails shops, stationary shops and communication centers became important income source in the society which introduced the locals with the modern technology as well.

7. Matured community has started to emerge where various investors started to invest by identifying the potential in the neighborhood. Moreover, the competition has resulted a pike in land values and new residential complexes started to emerge in the local context.

8. Because of the competition, locals started to upgrade their houses and residential buildings where it upgraded their built environment. Clean and personal hygiene started to improve in the social fabric.

New building types were entered into accommodation market such as apartments, annexes, boarding houses, commercial outlets to facilitate students' demand. The structure and features of the buildings have been changed into attach bathrooms, tiled floor, vertical bunk beds, study hall etc.

Mobile outlets such as late night shops, lunch kiosks and other small temporary food outlets emerged near the entrance of the university targeting students. These shops cannot be seen in public holydays and vacation periods.

However, similar studies done in foreign countries have found negative cultural impacts of studentification to the host community. But in Kadubedda neighborhood, it is observed a more positive 


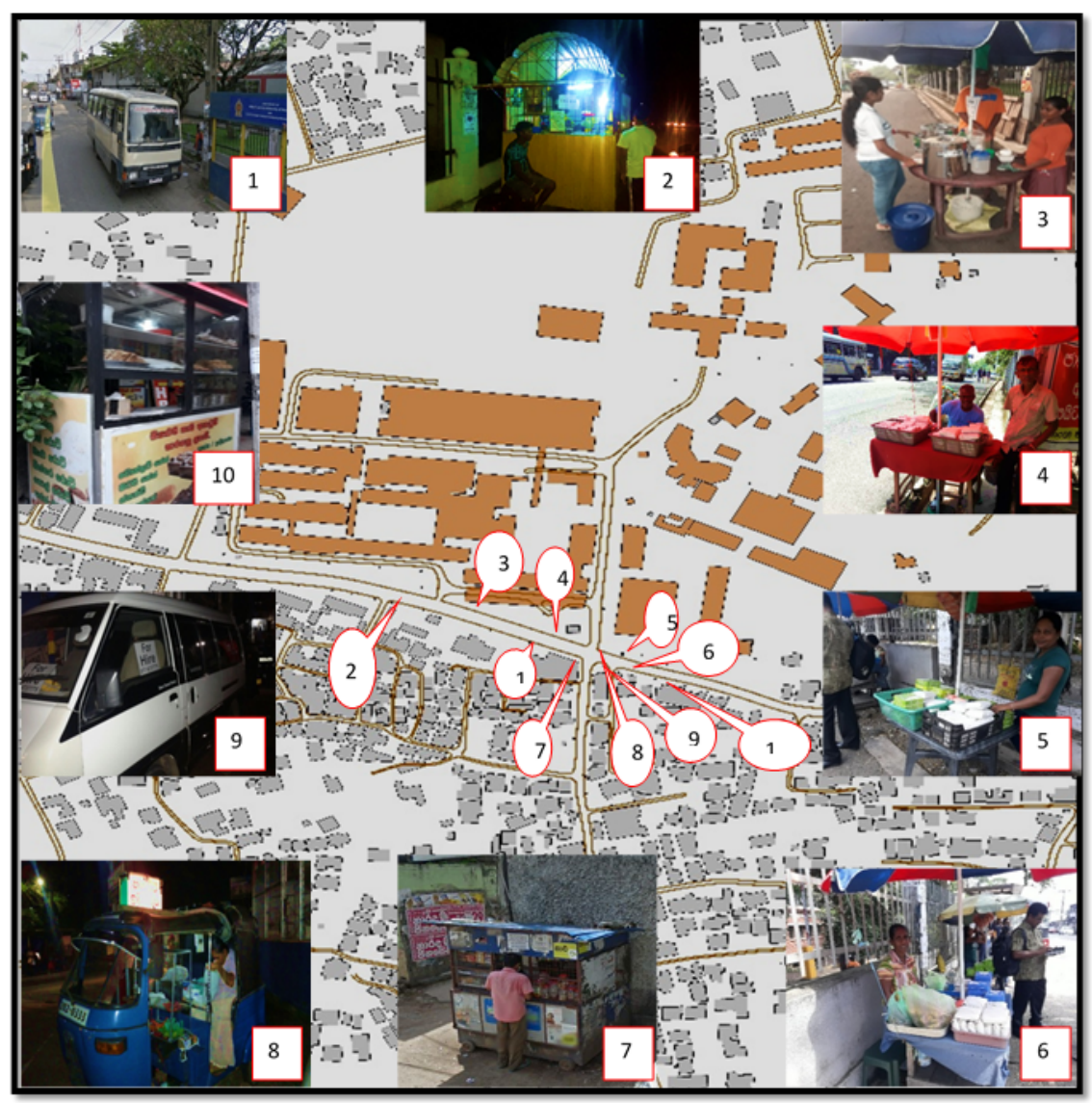

Figure 10. Distribution of Seasonal shops in the context

Source - Compiled by authors

impact on culture because the majority of locals jointly occupy properties without complete displacement which has resulted win-win situation for the host community as well as the students.

\subsection{Physical Changes}

When an area is gentrified the housing and other light industries are filtered both in value and quality (Smith N. , 1987). In terms of studentification it can be observed a similar kind filtering of students related land uses in the study area. Both the population density and the building density of the area also have increased rapidly. To facilitate these changes, new infrastructure facilities have been introduced into the area such as improved roads, three-phase electricity coverage, fiber optic networks, wifi-networks, pipe borne water, etc. These expansions have resulted degradation of vegetation cover of the area and the filling of low-land areas. High rise student apartments have resulted a different streetscape which is a new addition for the suburban setting of the neighborhood.

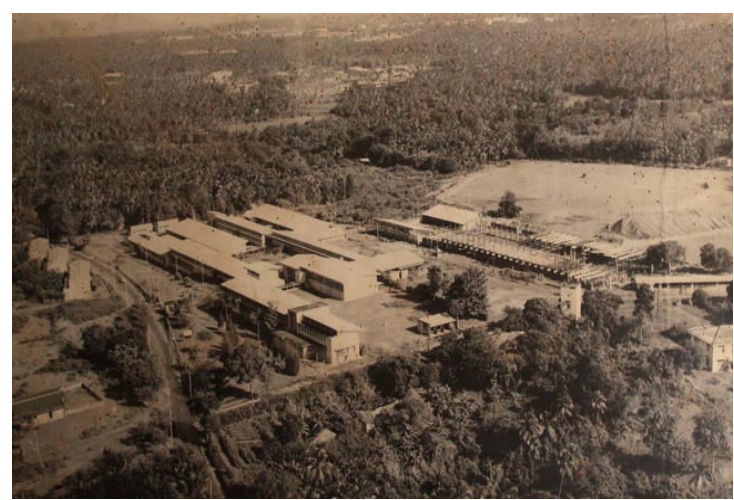

Figure 11. Old aerial photograph of the university premises where we can observe treescape and more vacant land areas in the backdrop. (1980)

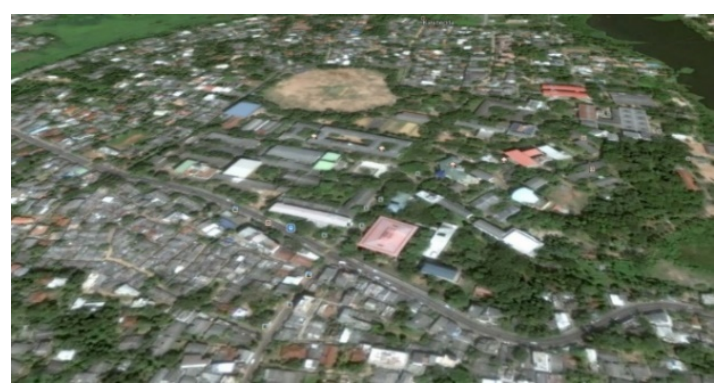

Figure 12. Present situation of the university context where we can observe the newly emerged residential buildings and deforestation 


\section{Conclusion}

This research attempted to investigate the process of studentification in Katubedda neighborhood. Studentification is a special form of gentrification where students become a dominating factor for the socio and cultural change in the urban fabric. The expansion of the University of Moratuwa, has stimulated a studentification process. Social modification appears to occur as a result of the student accommodations in the surrounding area. The study findings provide evidences for such studentification process. However, unlike past research in the western countries, this current study revealed some variation in the studentifcation happens in the study area in terms of its nature and the form.

The key economic changes identified in the neighborhood include the conversion of the houses into multiple occupancy targeting potential rents from students (Rent-seeking behavior). In terms of social changes, almost $20 \%$ of the residence have been displaced from their original location. However, the majority of house owners do share their houses with students which leads to the reduction of house space occupied by the owner compared to student occupied share. This is a special form of displacement which has not observed in previous research studies conducted in other countries.

Foreign case studies on studentification such as in UK Loughborough, have identified large negative impacts such as population disparity, lack of community cohesion, antisocial behavior, criminal damage and disorder and decay of physical landscape which resulted by young student community only grouped in a society where owners displaced from the area. When comes to the Sri Lankan context, people are not getting displaced, but reduce the owner-occupancy level which led to limit the negative impacts from the studentification. The important fact here is, owner retains some control over students' activities within the accommodation and students' culture has significantly transferred to owner families.

Physically the entire contextual landscape has been changed where more developed infrastructures are being integrated into the context. Further, new apartments are being emerged into the context which is for students and students-based housing is being introduced where the entire streetscape and its character have been changed. However negative consequences have been identified such as substandard housing, building without basic infrastructure and unauthorized buildings (buildings which do not follow regulations) with the intention of rent capturing from the growing student demands.

Further, students have inspired the families to approach higher calibers and various kinds of mix cultural synthesis started to emerge in the neighborhood. A tangible and intangible relationship occurred between students and the society which resulted the domination of the students in the neighborhood. Soon after the arrival of the University of Moratuwa various academic intuitions started emerging around the university premises which reinforced the accommodation demand of the students.

As a conclusion series of the process has occurred which resulted in studentification in Katubedda neighborhood. The studentification at an initial stage where the domination of the students has been spreading around the neighborhood. Especially, the pattern of studentification occurred in Katubedda neighborhood is different from foreign case studies in terms of displacement. However, in order to confirm this pattern more research is needed around other locations of studentification in Sri Lanka.

At the same time findings such as substandard buildings highlights the need of special regulations and strict enforcement for neighborhoods with impacts of studentification to ensure the health and safety of its inhabitants.

However, the above findings of the research are subject to several methodological and technical limitations. Since this is the first attempt to study the process of studentification around a university in Sri Lanka, the results cannot be compared nor generalized. At the same time, lack of time series real property datasets in Sri Lanka limited the depth of analysis in measures such as reinvestment capital and displacement. 


\section{References}

Arnott, R., Davidson, R., \& Pines, D. (1983). Housing quality, maintenance and rehabilitation. The Review of Economic Studies, 50(3), 467-494.

Butler, T., \& Lees, L. (2006). Super-gentrification in Barnsbury, London: globalization and gentrifying global elites at the neighbourhood level. Transactions of the Institute of British Geographers, 31(4), 467-487.

Clark, E. (2005). The order and simplicity of gentrification - a political challenge. In B.G. Atkinson (ed.). Gentrification in a Global Context:The New Urban Colonialism, 256-264.

Davidson, M., \& Lees, L. (2005). New-build 'gentrification'and London's riverside renaissance. Environment and planning A, 37(7), 1165-1190.

Davison, G. (2009). Carlton and the Campus: The University and the Gentrification of Inner Melbourne 1958-1975. Urban Policy and Research, 27(3), 253-264. doi:10.1080/08111140903118365

Dissanayake, C. (Ed.). (2014, 09 24). As Gentrification Encroaches, Owners of Colombo's Secondhand Bookshops Hope Next Chapter is Cheery. Retrieved from Global Press Journal :https://globalpressjournal.com/asia/sri_lanka/as-gentrification-encroaches-owners-ofcolombo-s-secondhand-bookshops-hope-next-chapter-is-cheery/

Ebenezer Aka. (2010). Gentrification andsocioeconomic impacts of neighborhood integration and diversification in Atlanta, Georgia. National Social Science Journal, 35(1), 1-13.

Gober, P. (1992). Urban housing demography. Progress in Human Geography, 16(2), 171-189.

Gotham, K. F. (2005). Tourism gentrification: The case of new Orleans' vieux carre (French Quarter). Urban studies, 42(7), 1099-1121.

Gotham, K. F. (2015). Tourism Gentrification: The Case of New Orleans' Vieux Carre (French Quarter). Urban Studies, 42(7), 1099-1121.

Holm, A. (2010). Townhouses, Urban Village, Car Loft. Berliner Luxuswohnanlagen als 'dritte Welle' der Gentrification. Geographische Zeitschrift, 98(2), 100-115.

Hubbard, P. (2008). Regulating the social impacts of studentification: a Loughborough case study. Environment and Planning A, 2(40), 323-341.

Kinton, C. (2013). Processes of destudentification and studentification in Loughborough. Loughborough University Institutional Repository, 25-47.

Lees, L. (2000). A reappraisal of gentrification: towards a 'geography of gentrification'. Progress in Human Geography, 24(3), 389-408.

Liu, C. (2016). An abstract model of gentrification as a spatially contagious succession process. Computers, Environment and Urban Systems, 59, 1-10.

Liu, C., \& O'Sullivan, D. (2016). An abstract model of gentrification as a spatially contagious succession process. Computers, Environment and Urban Systems, 59, 1-10.

Ordor, U., Cattell, K., Michell, K., \& Bowen, P. (2010). The effects of studentification on the residential neighbourhood of a university suburb:A study ofCape Town in Rondebosch. 
CIB W070 International in facilities management (pp. 546-552). Cape Town: FM in the experience economy.

Park, R., Burgess, E., McKenzie, R., \& Janowitz, M. (1925). The City: Suggestions of Investigation of Human Behavior in the Urban Environment. Chicago: University of Chicago Press.

Sabri, S., \& Muhamad Ludin, A. (2009). "Studentification" is it a key factor within the residential decision-making process in kuala lumpur? Faculty of Built Environment, Department of Urban \& Regional Planning,Universiti Teknologi Malaysia, 60- 79.

Sage, J. (2010). The Micro-Geographies of Studentification in Brighton and Hove. 96-114.

Samarawickrema, N. (2012, August). Remaking the fort: familiarization, heritage and Gentrification in Sri Lanka's Galle fort. pp. 15- 78.

Sampson, Robert J.; Wilson, William Julius;. (2012). Great American City. doi:10.7208/chicago/9780226733883.001.0001

Smith, D. (2004). 'Studentification ication': the gentrification factory? Gentrification in a global context, 73 .

Smith, D. P. (2006). Studentification and Moral Panic:When is a 'Student Area' a 'Student Ghetto'? The 3rd International Population Geographies Conference. United Kingdom: University of Brighton, UK.

Smith, N. (1987). Gentrification and the Rent Gap. Annals of the Association of American Geographers, 77(3), 462-465.

Smith, D. P., \& Holt, L. (2007). Studentification and 'apprentice'gentrifiers within Britain's provincial towns and cities: extending the meaning of gentrification. Environment and Planning A, 39(1), 142-161.

Smith, N. (2002). New Globalism, New Urbanism: Gentrification as Global Urban Strategy. Antipode, 34(3), 427-450. doi:10.1111/1467-8330.00249

University of Moratuwa. (2017). Retrieved from Mrt.ac.lk: https://www.mrt.ac.lk/web/history

Zuk, M., Bierbaum, A. H., Chapple, K., Gorska, K., \& Loukaitou-Sideris, A. (2015, march 03). Gentrification, Displacement, and the Role of Public Investment. Journal of Planning Literature, 3-11. doi:10.1177/0885412217716439 